\title{
TEACHING AFRICAN AMERICAN HISTORY AND CULTURE THROUGH COOKBOOKS AND ETIQUETTE MANUALS
}

\author{
Sakina M. Hughes \\ University of Southern Indiana
}

Malinda Russell was in a tough spot. Inspired by the back to Africa movement of the American Colonization Society, she saved her meager earnings, sold her belongings, and started on her journey to the meeting location of people going to Liberia. She made the trip by herself. Traveling solo made the trip a dangerous one, and a fateful one, as Russell was robbed of her money and belongings on the road to the Liberia meeting place. With no money and no way to carry out her dream of going to Liberia, Russell turned back to what she knew: cooking. She built a respectable business, cooking for well-to-do white clients. Eventually, tragedy struck again for Russell, and once more she relied on what she knew to get by. She decided to write a cookbook to raise money for herself and her children. This work, published in 1866, was the first known cookbook published by a black American woman in the United States. ${ }^{1}$

Black-authored cookbooks and etiquette manuals can be effective in the undergraduate classroom as primary documents to teach students about the biographies of individuals as well as larger trends in black history, culture, and race relations. In this article, I first argue for the importance of a variety of culinary works - cookbooks and etiquette manuals - from the nineteenth and twentieth centuries to demonstrate culinary books' contribution to a wide range of historical study. Then, I suggest sources that teachers and students can use in classrooms to investigate the lives of authors and their connections to American culture. Next, I offer a teaching method I used in one of my classes with particular reference to Malinda Russell's $1866 \mathrm{~A}$ Domestic Cook Book. Russell's life story opens a window for students to inquire about her unique challenges and the broader view of African American experiences in the middle of the nineteenth century. Finally, I reflect on how teachers of history may use cookbooks and etiquette manuals as primary sources to teach lessons on African American history and culture. ${ }^{2}$

\footnotetext{
'See Jan Longone, "Early Black-Authored American Cookbooks," Gastronomica: The Journal of Food and Culture 1 (Winter 2001): 96-99.
}

${ }^{2}$ Special thanks to the University of Michigan Clements Library and the Janice B. Longone collection of African American authored cookbooks and etiquette books. During my postdoctoral year at the University of Michigan, I helped to catalogue and curate an exhibit on the books that I will discuss in this essay. This article is an outgrowth of my work on the collection of black-authored works in the Janice Bluestein Longone Culinary Archive (JBLCA). Special thanks also to librarian Katie Loehrlein at the University of Southern Indiana David L. Rice Library for research assistance. 


\section{Cookbooks and Etiquette Manuals in Historical Study}

Diverse authors wrote cookbooks and etiquette manuals: a head butler in the New England home of a senator; a free woman of color who moved from the antebellum South to Paw Paw, Michigan; a cook who grew up in the Arkansas governor's mansion; a famous Civil Rights and Black Power leader; musicians, hoteliers, a renowned scientist, and many, many more authors from all walks of life. There were as many different reasons for writing as there are authors. Some authors stated that they desired to share their years of wisdom; others hoped to benefit the health of African Americans across the country; some wrote to make ends meet; others wrote in order to raise consciousness about culture, to educate about holiday traditions, and even to move toward racial justice and solidarity.

Culinary books hold a special place in the history of race and class. The first book of any kind by a black American printed by a commercial publisher in the United States was The House Servant's Directory by Robert Roberts, published in Boston in 1827 by Monroe and Francis. ${ }^{3}$ Three black-authored works followed in the nineteenth century: Tunis Campbell's Hotel Keepers, Head Waiters and Housekeepers ' Guide in 1848; Malinda Russell's A Domestic Cook Book: Containing a Careful Selection of Useful Receipts for the Kitchen in 1866; and Abby Fisher's What Mrs. Fisher Knows about Old Southern Cooking in 1881.

For decades few scholars paid close attention to the culinary history of America. Instead, historians relied on sources such as letters, diaries, journals, and government records. Today, we recognize food studies as an important tool of analysis in cultural and economic history. Food reflects both national and regional culture just as art, literature, music, politics, and religion do. ${ }^{4}$ Besides being publishing firsts for African Americans, cookbooks and etiquette books have wide social and political implications. The field of food studies has grown to encompass time, space, race, and class - all with the aim of explaining and interpreting food, society, and culture. ${ }^{5}$ Current studies take food beyond the realm of agricultural and economic history and give it the fuller meaning by leaning toward cultural explanations, concentrating on the symbolic importance of food items, the cultural patterns that they underscore, or their influence

${ }^{3}$ Robert Roberts, The House Servant's Directory (Boston: Munroe and Francis, 1827). Phyllis Wheatley's book of poetry, written in 1773, was published in England. So Roberts has the honor of being the first African American to publish in the United States.

${ }^{4}$ Marc Cohen Ferris, The Edible South: The Power of Food and the Making of an American Region (Chapel Hill: The University of North Carolina Press, 2014), 2.

${ }^{5}$ John C. Super, "Food and History," Journal of Social History 36 (Fall 2002): 165. 
on human behavior. ${ }^{6}$ Cookbooks appear in literate civilizations where the display of class hierarchies is essential to their maintenance, and where cooking is seen as a communicable variety of expert knowledge. ${ }^{7}$ Indeed, many early black authors used writing culinary works as a way of establishing their "professional" credentials and of contesting white racism in the process. ${ }^{8}$ These works can be ideal cultural symbols that allow the historian to uncover hidden levels of meaning in social relationships and arrive at deeper understandings of the human experience. ${ }^{9}$

Cookbooks provide wide-ranging implications for gender studies as well. Although the material practice of cooking is not necessarily gendered, the sociopolitical context in which cooking takes place often is. ${ }^{10}$ Even in the post-women's movement era, cooking and the food-related labor of women are often devalued or neglected due to the association of food and labor with masculinity, male celebrity, and bravado. Women's voices demand and deserve recognition because they are central to the culinary culture of our nation. ${ }^{11}$ Food opens a window through which we can look. For example, Doris Witt argues that cooking has special implications for the black woman not shared by either black males or whites. Because the black woman's options have traditionally been limited to domestic service, recipe-sharing assumes more the context of a battlefield, where the social barriers of class, race, and generation were not eradicated but constructed, maintained, and fortified. ${ }^{12}$ According to Patricia Hill Collins, black women in the last few decades have been paradoxically "portrayed as stupid; having an animal-like sexuality, a natural willingness to serve, and an innate ability to cook; demonstrating an endless strength in the face of racism and sexism, and a willingness to put anyone and everyone always before themselves. All these

${ }^{6}$ Ibid., 174.

${ }^{7}$ Arjun Appadurai, "How to Make a National Cuisine: Cookbooks in Contemporary India," Comparative Studies in History: An International Quarterly 30 (January 1988): 4.

${ }^{8}$ Doris Witt, Black Hunger: Soul Food and America (Minneapolis: University of Minnesota Press, 2004), 11-12.

${ }^{9}$ Super, "Food and History," 165.

${ }^{10}$ Rosalyn Collings Eves, "A Recipe for Remembrance: Memory and Identity in African-American Women's Cookbooks,” Rhetoric Review 24 (2005): 283.

${ }^{11}$ Witt, Black Hunger, 2.

${ }^{12}$ Ibid., 284. 
stereotypes as well as being generally bitchy and disagreeable."13 Cookbooks can counter such images of a flawed dominant cultural view of African American women by dictating their own parameters for a cultural counter-memory. ${ }^{14}$

Foodways studies confirm that more than being peripheral to women's lives, the culture of food is a source of information about how they contributed to cultural life. ${ }^{15}$ From the early slave women who passed on their knowledge to the more literate women of the twentieth century who passed down their written texts, recipes constitute rich sources on African American women, and these sources often run contrary to externally imposed gender and racial definitions.

Doris Witt's Black Hunger considered the relationship of music, minstrelsy, and food in black culture. She suggested that African Americans, in their guise as entertainers, "season the possum of black expressive culture" to the taste of their Anglo American audience, maintaining, in the process, their integrity as performers. But in the closed circle of their own communities, everybody knows that the punch line to the recipe and the proper response to the performer's constrictive dilemma is, "Damn the possum! That sho' is some good gravy!" Witt argues that the "gravy" is the inimitable technique of the Afro-American artist, derived from lived blues experience, as capable of "playing possum" as of presenting one. ${ }^{16}$ Witt concludes that if this "gravy" were understood only as technique, then the "lived blues of experience" of hunger would, quite the contrary, surely derive from its lack. It seemed just possible, in other words, that a materialist perspective ought to consider the "gravy" literally as gravy, food derived from the unremunerated labor of an African American culinary artist, usually a woman. In turn, her lived blues experience would perhaps derive from the fact that she was at work in the kitchen making gravy to cover the absence of meat while the men were out singing blues, playing possum - and awaiting dinner. ${ }^{17}$

Finally, region plays a role in cookbooks and etiquette manuals. For example, Marcie Cohen Ferris argues that throughout history, the politics of power and place has established complex regional cuisines of both privilege and deprivation that continue to impact daily food patterns of Americans. In the South, for example, whites, African Americans, and Native Americans struggled for control of their bodies and minds, nourishment, livelihood, land, and citizenship. In food lies the harsh dynamics of

\footnotetext{
${ }^{13}$ Patricia Hill Collins, Fighting Words: Black Women and the Search for Justice (Minneapolis: University of Minnesota Press, 1998), 8-9.

${ }^{14}$ Eves, “A Recipe for Remembrance," 281.

${ }^{15}$ Jacqueline Bobo, Black Feminist Cultural Criticism (Malden, MA: Blackwell, 2001), xvii.

${ }^{16}$ Witt, Black Hunger, 194-195.

${ }^{17}$ Ibid.
} 
racism, sexism, class struggle, and ecological exploitation that have long defined the South. There too, however, resides family, a strong connection to place, conviviality, creativity, and flavor. A tension underlies southern history, and that same tension resides in southern foodways, a cuisine largely shaped by the diverse racial history of the region. ${ }^{18}$ In the past, borders were more rigid on foodways. The map of the South traditionally referred to the eleven states of the former Confederacy, but today these rigid borders are more fluid. The South is found wherever southern culture is found, existing as a state of mind both within and beyond its geographical boundaries. ${ }^{19}$

\section{History, Culture, and Race Studies through Culinary Works: Examples of Cookbooks and Etiquette Manuals}

Cookbooks and etiquette manuals can be creative tools in teaching several aspects of black history. ${ }^{20}$ These documents can illustrate some of the diversity in the everyday lives of black people throughout American history. Malinda Russell's $A$ Domestic Cookbook: Containing a Careful Selection of Useful Receipts for the

\footnotetext{
${ }^{18}$ Ferris, The Edible South, 1.
}

${ }^{19}$ Ibid.

${ }^{20}$ Please see Liza Ashley, Thirty Years at the Mansion: Recipes and Recollections (Little Rock: August House, 1985); Leah Chase and Johnny Rivers, Down Home Healthy: Family Recipes of Black American Chefs (National Institutes of Health, National Cancer Institute, U.S. Department of Health and Human Services, 1994); Good Things to Eat as Suggested by Rufus: A Collection of Practical Recipes for Preparing Meats, Game, Fowl, Fish, Puddings, Pastries, ETC (Chicago: Rufus Estes, 1911); A. Fillmore, The Lone Star Cook Book and Meat Special (From the Slaughter Pen to the Dining Room Table) (Nashville: National Baptist Publishing Board, 1929); Abby Fisher, What Mrs. Fisher Knows about Old Southern Cooking: Soups, Pickles, Preserves, Etc. (San Francisco: Women's Co-operative Printing Office, 1881); Franklyn H. Hall, How to Make and Serve 100 Choice Broths and Soups (Philadelphia: Franklyn H. Hall, 1903); Bobby Hendricks, Barbeque with Mr. Bobby Que (Memphis: Wimmer Brothers Books, 1976); Mary Jackson and Leila Wishart, The Integrated Cookbook or The Soul of Good Cooking (Chicago: Johnson Publishing Company Inc., 1971); Bob Jeffries, Soul Food Cook Book (New York: The Bobbs-Merrill Company, 1969); Robert Roberts, The House Servant's Directory (New York: Charles S. Francis, 1827); Malinda Russell, A Domestic Cook Book: Containing a Careful Selection of Useful Receipts for the Kitchen (Paw Paw, Michigan: Malinda Russell, 1866). For related secondary sources, see: Elizabeth Clark-Lewis, Living In, Living Out: African American Domestics in Washington, D.C., 1910-1940 (Washington: Smithsonian Press, 1994); Elizabeth L. O'Leary, From Morning to Night: Domestic Service in Maymont House and the Gilded Age South (Charlottesville: University of Virginia Press, 2003); Rebecca Sharpless, Cooking in Other Women's Kitchens: Domestic Workers in the South, 1865-1960 (Chapel Hill: University of North Carolina Press, 2010); Tera Hunter, To 'Joy My Freedom: Southern Black Women's Lives and Labors After the Civil War (Cambridge: Harvard University Press, 1997). 
Kitchen is a prime example. ${ }^{21}$ Russell has an amazing story with which many students connected-from her life's struggles and hardships, to her bravery in facing those struggles, to the publishing, subsequent losing, and rediscovery of her book. Everything we know about her comes from the introduction she wrote in her cookbook. In addition to the rich autobiographical section in this work, the remainder of the book is comprised of recipes. The recipes include main dishes and side dishes, desserts, beverages, and breads. While most of the recipes are foods, Russell also includes household tips and medicinal recipes. Some of the medicinal items include recipes for hair oils and cures for toothaches and rheumatism. She, no doubt, used these very recipes when she was a traveling nurse.

Malinda Russell's book replaced another author, Abby Fisher, with the title of the earliest black-authored cookbook. Fisher's What Mrs. Fisher Knows about Old Southern Cooking: Soups, Pickles, Preserves, Etc. was published in 1881 and is still an important piece of African American and California publishing history. Mrs. Fisher was a former slave who could neither read nor write. She enlisted the help of several named benefactors to transcribe and publish the book. Fisher was born in South Carolina and moved to San Francisco where she established a successful business in pickle and preserves manufacturing. She gained culinary fame by winning medals and diplomas at several California fairs, including two medals in San Francisco in 1880 for "best pickles and sauces and best assortment of jellies and preserves." Fisher said that friends and colleagues encouraged her to publish a book of her original recipes. This was a common statement- that she had been encouraged by others - that we find in many black authored books of the time. It was a justification for having stepped beyond racial and class expectations to publish a book. ${ }^{22}$

This special class of primary sources also describes the work lives of African American chefs, domestics, and etiquette experts. Teachers might use these texts to examine how relationships between domestic employees and employers changed over the course of the nineteenth and twentieth centuries. Another prominent theme educators might consider is how domestic workers viewed their labor and their particular expertise. Researchers may also explore how black domestic workers made decisions to migrate for professional, educational, or other reasons. Since racial betterment is a central theme in many of the books, researchers and students may ascertain evolving ideas about racial uplift. The House Servant's Directory by Robert Roberts is a particularly relevant example. Roberts was a black American domestic

\footnotetext{
${ }^{21}$ The Janice Bluestein Longone Culinary Archive of African American Cookbooks has the distinction and honor of possessing the only known copy of this central work in African American publishing history. It is now available digitally online through the University of Michigan.
}

${ }^{22}$ Abby Fisher, What Mrs. Fisher Knows about Old Southern Cooking: Soups, Pickles, Preserves, Etc. (San Francisco: Women's Co-operative Printing Office, 1881). 
servant who lived from about 1780 to 1860 . He worked at the country estate of Christopher Gore, the governor of Massachusetts and a United States Senator. The first known book written by an African American and published by a commercial press in America, this manual offers one of the most detailed discussions on the proper management of a nineteenth-century upper-class New England household. Additionally, and even more fascinating, it is the first self-help book published to encourage young black men to become professionals. Roberts offers specific, practical advice on how to ensure a determined young man's career advancement.

The House Servant's Directory provides a variety of information on the work and life of domestic servants, as well as a description of the ideal domestic servant. Roberts focuses on how to run a large household, how to maintain desirable relationships with employers and other servants, and how to build a respectable professional reputation. The book includes recipes for food, cleaning, and remedies for common ailments. In a section for cooks, Roberts describes the importance of keeping good relations with other servants and proper etiquette to exercise when working with other employees. Additionally, this guide gives some advice to employers on how to treat servants. All this said, this book provides a glimpse into the lives of northernbased domestic servants on wealthy estates. While a dominant theme throughout the work is the importance of knowing one's own place within the household, it illustrates the resources at their disposal, their social status, and their prospects for career advancement.

Taking readers into the twentieth century and the era of African American racial uplift ideology, Edward S. Green's 1920 publication, The National Capital Code of Etiquette Dedicated to the Colored Race, is another powerhouse for black history and culture. Green worked for the United States government for eighteen years. He graduated from college and was a recognized man of letters and literacy among upperclass African Americans and diplomatic circles in Washington, D.C. and abroad. His work is an etiquette book aimed at teaching black people of all walks of life the customs of the African American social elite. Subjects include how to dress for various occasions, correct table manners, how to conduct oneself in public, styles for calling cards, and how to introduce friends and business acquaintances. Green also devotes much of the book to the art of conversation: how to commemorate wedding anniversaries, how to properly conduct social calls and activities, and proper mourning practices. Green includes several charts and photographs throughout the book to illustrate proper attire, place settings, and room decorations. Photographs of the author and his wife are also included. In fine, granular detail, this book illustrates the values and high culture of middle- and upper-class African Americans during a time when race 
leaders advocated the philosophy of racial uplift. This book takes students to a place of understanding the very detailed codes of conduct and social expectations. ${ }^{23}$

Cookbooks may also be a tool to understand African American political movements. Authors show links between food and political activism in black history. A dominant theme among these works is the relationship between late twentieth-century activism and the rise of the Soul Food Movement. Cookbook authors wrote directly about their involvement in the 1960s and 1970s student movements, labor unionism, Civil Rights activism, and the Black Panther Party for Self Defense. Published in Berkeley in 1988, Barbeque' $n$ with Bobby by Bobby Seale, is an excellent example of a black activist authoring a cookbook. This cookbook serves as a springboard to investigate the life and social activism of Bobby Seale and the community work of the Black Panthers. During the 1960 s, Seale was a part of the New Left student protest movement. Inspired by the advent of the Civil Rights Movement, Dr. Martin Luther King, Jr., and Malcolm X, Seale co-founded the Black Panther Party for Self Defense in October 1966. During the eight years that Seale was chairman of the Black Panther Party, he initiated community-based service programs such as breakfasts for school children, but he reached international notoriety during the Chicago Eight Conspiracy trial of 1969-1970. His cookbook, like so many others, opens with an autobiography that is rich in detail. The remainder of the book includes recipes and suggests ways to build a barbeque fire and the best types of supplies to use. ${ }^{24}$

Many cookbooks deal with issues of gender directly or indirectly. For any woman, the act of cooking has overlapping social meanings and notions of her traditional roles. Gender and race further complicate the experiences of African American female cooks. Especially in etiquette manuals, researchers may explore the differing roles and expectations of male and female domestic workers. In The House Servant's Directory, Robert Roberts' advice to the heads of families is a window to the world of female domestic workers. As he advises the heads of families on how to treat them, readers discover some of the challenges of female cooks in the nineteenth century. Roberts wrote that the man of the house should take the greatest care to preserve his cook's health:

Ye, who think that to protect and encourage virtue, is the best preventive from vice, give your female servants liberal wages .... To say nothing of the deleterious vapours and pestilential exhalations of the charcoal, which soon undermine the health of the heartiest, the glare of a scorching fire, and the smoke so baneful to the eyes and the complexion, are continual

\footnotetext{
${ }^{23}$ Edward S. Green, The National Capital Code of Etiquette Dedicated to the Colored Race (Washington, D.C.: A.N. Jenkins, 1920).
}

${ }^{24}$ Bobby Seale, Barbeque'n with Bobby (Berkeley: Ten Speed Press, 1988). 
and inevitable dangers; and a cook must live in the midst of them, as a soldier on the field of battle, surrounded by bullets, and bombs, and Congreve's rockets, with this only difference, that for the first, every day is a fighting day, that her warfare is almost always without glory, and most praiseworthy achievements pass not only without reward, but frequently without even thanks; for the most consummate cook is, alas! seldom noticed by the master, or heard of by the guests .... Cleanliness, and a proper ventilation to carry off smoke and steam, should be particularly attended to in the construction of a kitchen; the grand scene of action, the fire-place, should be placed where it may receive plenty of light. Hitherto the contrary has prevailed, and the poor cook is continually basted with her own perspiration. ${ }^{25}$

Roberts compared the kitchen to a battleground and the cook's plight to that of a soldier and unsung hero. Her workplace undermined her health, as she was subjected daily to scorching fire and noxious smoke. Fair wages, cleanliness, and ventilation in the kitchen were also points of concern for Roberts. One reads this as a common problem among cooks during this period. Students of these sources may also study the differences in opportunities within households and business establishments that were available to men and women employees. The relationships between male and female employees may also be researched.

In addition, cookbooks reveal changes in African American attitudes toward food and migration. In particular, they reveal changing ideas about how food reflects culture and the relationship between diet and health. Students may study attitudes about food in black communities that have shifted between economic and subsistence needs, cultural awareness, and health concerns. The emphasis on Soul Food cooking also made way for healthful eating as African American chefs raised awareness of the relationship between diet and conditions such as diabetes and heart disease. The works also point to the cultural influence of Soul Food and southern cooking in northern cities.

African American cookbooks also deal indirectly with migration, often south to north, but also north to south, and interregional movement. These books reveal why certain authors left their homes, often to find work, and how their travel led to different types of employment. The works give insight into what the authors saw as benefits to living in certain regions compared to others. In some cases, failed attempts to travel or to emigrate are described - for example, Malinda Russell's failed attempt to travel to Liberia. The ability to escape the violence of the South through migration, thus taking her Tennessean recipes to Virginia and ultimately to Michigan, was of great importance to Russell. After being attacked by a guerilla party, she wrote, "Hearing that Michigan

\footnotetext{
${ }^{25}$ Roberts, The House Servant's Directory, 157-158.
} 
was the Garden of the West, I resolved to make that my home.” In Michigan, Russell did what she knew best-she began to cook again.

Finally, many cookbooks speak directly to cultural movements and intra-racial politics. In particular, these books might be used to examine shifting ideas about how food, etiquette, and social functions relate to ideas about racial uplift, culture, and social betterment in the nineteenth and twentieth centuries. Researchers may study how ideas of racial uplift, Black Nationalism, Civil Rights, and Black Power are reflected in the ways people write about food and etiquette. Cookbooks can reveal power relations between domestic workers and their employers. Researchers may note how each author dealt with these relationships and how each author defined the ideal servant. A prominent theme is how a servant may best fit into a household. Knowing one's place, how to show proper deference to those of higher social status and how to exercise responsibility with those of lower status is of great importance. In his House Servant's Directory, Robert Roberts wrote, “... there are many young men ... who oftentimes are deficient of some of the several branches that are requisite for a perfect servant to understand; I therefore have a sincere wish to serve all those who are in that capacity of earning an honest living, and perhaps are not perfect in the several branches of their business ... without being ordered by the lady in the family." ${ }^{26}$ Students conducting research may compare and contrast African American authored cookbooks and African American authored books "as told to" white co-authors. Both types of books cover the nineteenth century and twentieth century. Students might also find attitude shifts among African American authors through common locution. African American authors in the earlier part of the nineteenth century often wrote apologies for the so-called presumption of publishing a book on their own expertise, given their social status. By the turn of the twentieth century, African American authors took a more self-laudatory tone in their writings and emphasized their expertise in the culinary arts. Other selections touch on changing racial attitudes. Black and white activists of the Abolitionist movement as well as more modern partnerships in the twentieth and twenty-first century point to interracial collaboration as activism and as social movements.

In an introduction to Mahalia Jackson Cooks Soul, the famous singer describes the Soul movement and suggests that this book contributes to Soul Culture by providing traditional recipes from African American cultures and history. Jackson's powerful contralto voice enabled her to achieve international fame through her gospel music career. She recorded dozens of records and was known as "The Queen of Gospel." Jackson was also involved in the Civil Rights Movement. Jackson wrote that the

\footnotetext{
${ }^{26}$ Ibid., 2.
} 
unifying attribute of Soul Food - no matter the region of origin - is that it reflects the courage, action, and fervor of black people throughout history. ${ }^{27}$

A Kwanzaa Celebration: Festive Recipes and Homemade Gifts from an AfricanAmerican Kitchen by Angela Shelf Medearis is another example of learning culture through cookbooks. This work is both a book of recipes and a primer on the Kwanzaa holiday. Medearis described the historical roots and cultural importance of Kwanzaa. She introduced each of the seven principles of Kwanzaa, or Nguso Saba, and described dishes that are related to or represent each principle. Each chapter begins with a quote about a principle of Kwanzaa and ways that individuals and communities may celebrate that principle. Recipes are generally listed one per page, with ingredients and preparation instructions. Recipes are derived from African American and African traditions. Recipes are also prefaced with a short paragraph on how this particular food relates to Kwanzaa and African American history and culture. The book concludes with a Kwanzaa/Swahili pronunciation guide and glossary. ${ }^{28}$

\section{The Teaching Method}

The aim of this assignment is to aid students in recognizing the voice of a nineteenth-century African American female cookbook author. Students were to ascertain Malinda Russell's life story, the challenges she faced that were common to African Americans during her lifetime, her unique personal challenges, and the larger picture of what life entailed for an African American during and immediately following the Civil War.

I designed this assignment for students in a History 101 survey course at the end of a semester during which they had studied various primary documents and answered guiding questions. The students had studied various levels of servitude including slavery, indentured servitude, apprenticeships, and free-labor domestic service. The overarching question for the course considered how definitions of American freedom change over time, often to include more and more groups into the idea of liberty to all. This was the first assignment in which the students were required to generate their own hypothesis regarding the source, to become researchers, and to ascertain as much information as they could find to create a story about the cookbook author.

While I designed this assignment for a survey course, it could also be adapted for upper-division courses on women's history, African American history, and research methods. At the survey level, it was intended to introduce the value of primary sources; students should be expected to have a basic understanding of African American history

\footnotetext{
${ }^{27}$ Mahalia Jackson, Mahalia Jackson Cooks Soul (Nashville: Aurora Publishers Incorporated, 1970).

${ }^{28}$ Angela Shelf Medearis, A Kwanzaa Celebration: Festive Recipes and Homemade Gifts from an African-American Kitchen (New York: Dutton, 1995).
} 
before engaging in the assignment. For upper-division courses, more background in women's history and African American history could highly augment the assignment by giving students a richer context in which to place authors, enabling the students to delve deeper into researching the implications of gender, race, and class that this cookbook and others offer.

The Malinda Russell book that was used in this assignment was published in 1866. Before starting the assignment, students reviewed information regarding the period from lectures and their textbook about the triumphs, challenges, and perils of freed black people during the post-Civil War Reconstruction Era. They reflected on the promise of freedom in the Emancipation Proclamation and the $13^{\text {th }}$ Amendment versus what the text said about the lived experiences of African Americans. Russell's book is a treasure of information about an individual's struggle to survive and the struggle that also reflects many of the trials and tribulations of her contemporaries. The importance of freedom, or acknowledging freedom, is reflected in the opening lines of the autobiography section. Russell wrote, "I was born in Washington County, and raised in Green County, in the eastern part of Tennessee. My mother, Malinda Russell, was a member of one of the first families set free by Mr. Noddie, of Virginia." ${ }^{29}$ In the first two lines of her autobiography, Russell provides readers with specific details and context.

Students were instructed to form groups of four. They were given copies of $A$ Domestic Cook Book by Malinda Russell and asked four questions:

1. In your small groups, find out everything you can about the author. List the information in bullet-point format below. [Students should focus on sourcing the document: Who is the author? What is the title? Who was the intended audience? What were possible motivations for writing the book?]

2. What is the time period and geographic location? List what you can learn about the time and place this book was written. [Students' focus is on contextualizing sources.]

3. Is this a reliable historical source? Why or why not? [Students' focus is on corroborating sources.]

4. What trends in black history can you see through Russell's life?

Students were given thirty minutes to complete this activity. After the thirty minutes were up, students came back into the large group to discuss their findings. Students uncovered several pieces of information about Russell's life, the time period, and geographic location. Most prominent in student responses was biographical information. Students reported that Malinda Russell was born and raised in Washington and Green counties in eastern Tennessee, and that her mother was born

\footnotetext{
${ }^{29}$ Russell, A Domestic Cook Book: Containing a Careful Selection of Useful Recipes for the Kitchen.
} 
free after her grandmother was set free by a Mr. Noddie of Virginia. Students ascertained that at nineteen, Russell decided to go to Liberia but met tragedy along the way. En route to the Liberia meeting, one of her fellow travelers stole her money, and she was forced to stay in Virginia. In Virginia, Russell worked as a cook and a traveling nurse for women. Students were impressed by Russell's determination to make ends meet. In addition to cooking and working as a nurse, she also kept a washhouse, which she advertised in a local newspaper. While in Virginia, Russell married Anderson Vaughan. After her husband's death, Russell returned to Tennessee and kept a boarding house for three years, followed by a pastry shop for six years. By 1864 , Russell had once again saved a considerable amount of money, but it was stolen. The group that stole her money this time threatened to kill her, and she decided to move to Michigan. At the time of writing A Domestic Cook Book, Russell was a widow and was supporting a son with a physical disability. Students recognized that Russell hoped the cookbook would benefit the public. However, she also hoped that her earnings from the book would help her to raise money and reclaim part of her property.

While most groups identified the book's contents as a firsthand account of a person's life and work and concluded that it was a valid primary source, two of the six groups of students did not recognize Russell's book as a primary source. Their responses were that this was not reliable because only one woman was involved in writing the book and that a cookbook should be rejected as a primary source. This error was corrected during discussion when the class reviewed the requirements and characteristics of primary sources. Overall, students identified trends in black American history that supported previous coursework and answered central questions of the assignment. Students' understanding of the time period were greatly enhanced by such a personal account of an individual who encountered many of the struggles others of her background also faced.

The aim of this assignment was to aid students in recognizing the voice of a nineteenth-century African American woman during and just after the Civil War by using a cookbook. Etiquette books may be utilized in similar ways. If this assignment had used an etiquette book, the same four questions could be asked. In addition to the four questions, students might be given extra questions such as:

1. How specifically does this etiquette advice reflect notions of African American racial uplift of the era?

2. In what ways does this etiquette advice reflect a class bias?

3. How does this book reflect gender norms of the era?

\section{Conclusion}

Cookbooks and etiquette manuals are unique windows into the histories of black Americans. Many cookbooks contain detailed autobiographies of the authors who provide their lives' stories as well as their reasons for writing their cookbook. These 
short autobiographies may show trends in black culture, highlight aspects of black history, and put the authors' lives in the context of their historical time period. Etiquette manuals, too, provide rich information. In addition to providing author autobiographies, etiquette manuals provide readers with detailed information of the norms and expectations of social interaction in the given historical period. The books show, for instance, changing ideas about how food, etiquette, and social functions related to ideas about racial progress and social betterment in the nineteenth and twentieth centuries.

Cookbooks and etiquette manuals reveal some important themes in black history. They reveal a rich diversity in experience. Authors wrote and published in all parts of the country - from New England to the Deep South to the West and Middle West. This regional diversity illustrates African American culinary influence in every corner of the country. ${ }^{30}$ We see some of the strongest and longest lasting themes of African American history in these books. They show the importance of economic and regional mobility to black people. They reinforce the importance of education in black communities. They illustrate the desire to pass on valued traditions and wisdom. And perhaps more literally than any other historical source, these books show students how throughout their experiences in the United States, black Americans have taken lemons and made lemonade. ${ }^{31}$

\footnotetext{
${ }^{30}$ Many of these themes come out in the finding aid. I organized the finding aid into research topics of potential interest. They include: African American Political Movements; African American Labor History; Gender; African American Health and Nutrition; African American Immigrant; Race Relations; and African American Cultural and Social Relations. However, I believe that as more researchers explore this collection, many more topics and uses will be found.

${ }^{31}$ For lemonade recipes see Liza Ashley, Thirty Years at the Mansion: Recipes and Recollections (Little Rock: August House, 1985).
} 